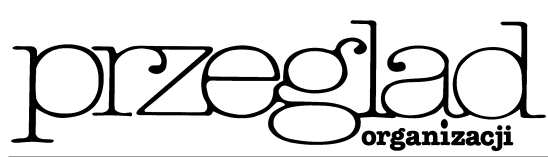

\title{
Decyzje o wykupie akcji własnych
}

https://doi.org/10.33141/po.2005.10.08

\section{Andrzej Rutkowski}

\section{Wstęp}

$\mathbf{P}$ odstawowym celem funkcjonowania spółki jest maksymalizacja wartości dla akcjonariusza. Właściciel powierza spółce swój kapitał i oczekuje satysfakcjonującej stopy zwrotu przy akceptowanym poziomie ryzyka. W kalkulacjach tych nie jest ważny wzrost wartości spółki, lecz wzrost przypadający na jednostkę zaangażowanego kapitału. Jeżeli akcjonariusz nie osiagga tych korzyści, to rozważa realokację zaangażowanego kapitału. Wykup własnych akcji przez spółkę i oddanie w ten sposób właścicielom nadwyżkowych kapitałów daje im możliwość alternatywnego, bardziej efektywnego zaangażowania zwolnionych kapitałów. Decyzje o wykupie własnych akcji, ocena ich efektywności należą do najtrudniejszych w spółce. Wykup akcji własnych można traktować jako:

- decyzje o wypłacie akcjonariuszom dodatkowych funduszy, które stanowią alternatywę dla dywidend, - decyzję inwestycyjną o określonej stopie zwrotu,

- decyzję kształtującą strukturę kapitału i strukturę akcjonariatu (właścicielską).

Jest to jednocześnie decyzja finansowa i inwestycyjna, o znaczących konsekwencjach dla działalności operacyjnej. Ma prowadzić do bardziej efektywnego wykorzystania nadwyżkowych funduszy, wpływa na strukturę kapitału.

Decyzja o wykupie własnych akcji jest podejmowana, gdy w spółce występuje nadmiar środków pieniężnych, które nie są potrzebne do sfinansowania działalności operacyjnej lub też dostępne są środki pożyczkowe, które mogą zastąpić kapitał własny. Poprzez wykup spółka decyduje się na zmianę struktury finansowania, na większy udział długu i wyższy poziom dźwigni finansowej. Wydatek na wykup własnych akcji można potraktować jako bezpieczniejszą formę inwestycji, jako alternatywę dla innych zamierzeń rozwojowych, np. w formie przejęcia innej jednostki.

Wykupy stanowią ważny sygnał informujący o optymizmie kierownictwa firmy, o jego przekonaniu, że akcje są aktualnie nie dowartościowane, że rynek nie docenia pełnych perspektyw rozwojowych analizowanej spółki. Ponadto mają one zapobiec spadkom cen akcji. Jednocześnie informują, że kierownictwo spółki nie dysponuje odpowiednio atrakcyjnymi projektami inwestycyjnymi. Ich realizacja mogłaby zmniejszyć efektywność zaangażowanych kapitałów. W takiej sytuacji lepiej jest zainwestować kapitały poza firmą.
Przegląd Organizacji, Nr 10 (789), 2005, ss. 33-36 www.przegladorganizacji.pl Towarzystwo Naukowe Organizacji i Kierownictwa (TNOiK)

\section{Statystyka wykupów akcji własnych}

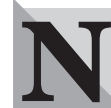

a rynku kapitałowym zaobserwować można rosnące znaczenie procesów wykupów własnych akcji (tab. 1). W drugiej połowie lat 90. ub. wieku na rynku amerykańskim kwoty przeznaczone na wykupy przewyższały wpływy z emisji akcji ${ }^{1}$.

Wykupy akcji własnych stają się popularne również na polskim rynku kapitałowym. Wykupy akcji własnych stanowią przedmiot gruntownych badań2). Nasilenie tego zjawiska na Warszawskiej Giełdzie Papierów Wartościowych prezentuje tabela 2. Badaniami objęto 218 spółek przemysłowych, budowlanych i handlowych funkcjonujacych na WGPW na koniec 2004 roku. Pominięte zostały banki, ubezpieczyciele oraz fundusze inwestycyjne. Przedstawione w badaniu wykupy nie oznaczają umorzenia akcji.

W analizowanym okresie coraz większa liczba spółek podejmuje się wykupów akcji. W kolejnych latach wartość transakcji waha się znacząco, osiagając rekordowy poziom w 2003 roku. W tym samym 2003 roku została przeprowadzona również największa liczba transakcji wykupu. Jednocześnie w analizowanym okresie 2000-2004 zgodnie z deklaracjami zarządów znacznie większa liczba spółek planowała podjąć tego rodzaju działania.

Tab. 1. Wykupy akcji własnych na rynku Stanów Zjednoczonych

\begin{tabular}{|c|c|c|}
\hline Rok & $\begin{array}{c}\text { Liczba } \\
\text { wykupów }\end{array}$ & $\begin{array}{c}\text { Wartość } \\
\text { (mln USD) }\end{array}$ \\
\hline 1998 & 1726 & 218577 \\
\hline 1999 & 1346 & 141612 \\
\hline 2000 & 773 & 166277 \\
\hline 2001 & 651 & 155536 \\
\hline 2002 & 472 & 119470 \\
\hline 2003 & 489 & 93162 \\
\hline 2004 & - & $230000^{*}$ \\
\hline 2005 (I kwartał) & - & $50000^{* *}$ \\
\hline
\end{tabular}

Źródło: M. BANYI, E.A. DYL, K.M. KAHLE, Measuring Share Repurchases, Working Paper Oregon State University, kwiecień 2005. *, ** Szacunek na podstawie: R. DOBBS, W. REHM, The Value of Share Buyback, „McKinsey Quarterly", nr 3, 2005. 
Tab. 2. Wykupy akcji własnych oraz dywidendy na WGPW w latach 2000-2004

\begin{tabular}{|l|r|r|r|r|r|}
\hline & $\mathbf{2 0 0 0}$ & $\mathbf{2 0 0 1}$ & $\mathbf{2 0 0 2}$ & $\mathbf{2 0 0 3}$ & $\mathbf{2 0 0 4}^{*}$ \\
\hline Liczba transakcji wykupów akcji własnych & 9 & 12 & 18 & 26 & 14 \\
\hline Wielkość wydatków na wykup akcji (tys. zł) & 63268 & 67048 & 149207 & 227300 & 161914 \\
\hline
\end{tabular}

Źródło: opracowanie własne na podstawie sprawozdań finansowych spółek giełdowych prezentowanych w serwisie „Notoria”. * Obliczenie dla roku 2004 częściowo zostały oparte na prognozach wyników dla niektórych analizowanych spółek.

Tab. 3. Wykupy akcji własnych oraz dywidendy na WGPW w latach 2000-2004

\begin{tabular}{|l|c|c|c|c|c|}
\hline & $\mathbf{2 0 0 0}$ & $\mathbf{2 0 0 1}$ & $\mathbf{2 0 0 2}$ & $\mathbf{2 0 0 3}$ & $\mathbf{2 0 0 4}$ \\
\hline Wielkość wydatków na dywidendy (tys. zł) & 362230 & 870444 & 282051 & 1097455 & 1316226 \\
\hline $\begin{array}{l}\text { Relacja wydatków na wykupy akcji własnych } \\
\text { do wypłat dywidend }\end{array}$ & $17,47 \%$ & $7,70 \%$ & $52,90 \%$ & $20,71 \%$ & $12,30 \%$ \\
\hline $\begin{array}{l}\text { Wydatki na wykup akcji i dywidendy } \\
\text { razem (tys. zł) }\end{array}$ & 425498 & 937492 & 431258 & 1324755 & 1478140 \\
\hline $\begin{array}{l}\text { Relacja wydatków na wykupy akcji własnych } \\
\text { do sumy wydatków na wykupy i dywidendy }\end{array}$ & $14,87 \%$ & $7,15 \%$ & $34,60 \%$ & $17,16 \%$ & $10,95 \%$ \\
\hline
\end{tabular}

Źródło: opracowanie własne na podstawie sprawozdań finansowych spółek giełdowych prezentowanych w serwisie „Notoria”. * Obliczenie dla roku 2004 częściowo zostały oparte na prognozach wyników dla niektórych analizowanych spółek.

Wykupy akcji własnych odgrywaja znacząca rolę jako alternatywny dla dywidend sposób realizacji korzyści dla właścicieli. Zjawisko to obrazuje tabela 3 . Przykładowo w 2002 roku w grupie badanych 218 spółek wydatki poniesione na wykupy wyniosły $52,90 \%$ wydatków na dywidendy i jednocześnie 34,60\% ogółu transferów środków do właścicieli.

Wykupy wpływają również na optymalną alokację środków z punktu widzenia całego rynku kapitałowego. Pozwalają na transfer kapitałów między poszczególnymi sektorami. Jednocześnie uszanowane zostają oczekiwania akcjonariuszy, którzy dążą do maksymalizacji swojego majątku również poza daną spółka. Minimalizowane są koszty agencji. Decyzje przedsiębiorstwa rozpatrywane sa w kontekście sposobności pojawiających się dla akcjonariuszy na całym rynku kapitałowym, a nie tylko w konkretnej spółce. Wykupy akcji zwalniają zaangażowane w sposób nieefektywny środki.

Wykupy akcji własnych mogą być traktowane jako alternatywny sposób inwestowania, przynoszaccy większy przyrost wartości dla akcjonariuszy w porównaniu z innymi przedsięwzięciami. Tabela 4 prezentuje (dla grupy badanych 218 spółek) relacje wydatków na wykupy do wydatków inwestycyjnych ogółem oraz do wydatków na inwestycje w aktywa finansowe.

W latach 2003-2004 wydatki na wykupy przekroczyły $1 \%$ ogółu wydatków inwestycyjnych oraz osiągnęły około $2 \%$ wydatków na aktywa finansowe.

Badania przeprowadzone na rynku amerykańskim przez Gupa i Nama ${ }^{3)}$ wykazały, że spółki podejmujące wykupy akcji osiagają wyższe efekty ekonomiczne niż pozostałe spółki, prowadzą do znaczącego wzrostu ekonomicznej wartości dodanej (EVA).

Na polskim rynku kapitałowym można zauważyć zmiany cen akcji jako reakcje na prowadzone wykupy (tab. 5). W latach 2003 i 2004 w grupie spółek, w których przeprowadzono wykupy ceny akcji wzrosły średnio zdecydowanie powyżej wzrostów indeksu WIG. W większości przypadków w roku przeprowadzania wykupu rynek pozytywnie ocenił wykup. W krótkim okresie widać pozytywne skutki dla ceny akcji spółek, w których dokonano wykupu. Wyjątkiem jest rok 2002, kiedy w grupie spółek dokonujących wykupu ceny akcji średnio spadły w większym stopniu niż we wszystkich spółkach giełdowych.

Tab. 4. Wydatki na wykupy akcji własnych $w$ relacji do wydatków inwestycyjnych na WGPW w latach 2000-2004

\begin{tabular}{|l|c|c|c|c|c|}
\hline & $\mathbf{2 0 0 0}$ & $\mathbf{2 0 0 1}$ & $\mathbf{2 0 0 2}$ & $\mathbf{2 0 0 3}$ & $\mathbf{2 0 0 4}$ \\
\hline $\begin{array}{l}\text { Wielkość wydatków inwestycyjnych } \\
\text { ogółem (tys. zł) }\end{array}$ & 22045390 & 22736134 & 17456451 & 19074309 & 14754983 \\
\hline $\begin{array}{l}\text { Relacja wydatków na wykupy akcji własnych } \\
\text { do wydatków inwestycyjnych ogółem }\end{array}$ & $0,29 \%$ & $0,29 \%$ & $0,85 \%$ & $1,19 \%$ & $1,10 \%$ \\
\hline Inwestycje w aktywa finansowe (tys. zł) & 11898208 & 13072567 & 10912644 & 12182423 & 6822771 \\
\hline $\begin{array}{l}\text { Relacja wydatków na wykupy akcji własnych } \\
\text { do wydatków na inwestycje w aktywa finansowe }\end{array}$ & $0,53 \%$ & $0,51 \%$ & $1,37 \%$ & $1,87 \%$ & $2,37 \%$ \\
\hline
\end{tabular}

Źródło: opracowanie własne na podstawie sprawozdań finansowych spółek giełdowych prezentowanych w serwisie „Notoria”. * Obliczenie dla roku 2004 częściowo zostały oparte na prognozach wyników dla niektórych analizowanych spółek. 
Tab. 5. Zmiany ceny akcji w roku przeprowadzenia wykupu akcji własnych na WGPW

\begin{tabular}{|l|c|c|c|}
\hline & $\mathbf{2 0 0 2}$ & $\mathbf{2 0 0 3}$ & $\mathbf{2 0 0 4}$ \\
\hline Indeks WIG na koniec roku & 14367 & 20820 & 26636 \\
\hline Zmiana indeksu WIG w ciągu roku & $104,37 \%$ & $144,92 \%$ & $127,94 \%$ \\
\hline Zmiana cen akcji w ciągu roku w spółkach dokonujących wykupu (mediana) & $94,98 \%$ & $181,62 \%$ & $150,89 \%$ \\
\hline Udział spółek ze wzrostem cen akcji powyżej wzrostu indeksu WIG & $44 \%$ & $76 \%$ & $75 \%$ \\
\hline Udział spółek ze wzrostem (spadkiem) cen akcji poniżej wzrostu indeksu WIG & $56 \%$ & $24 \%$ & $25 \%$ \\
\hline
\end{tabular}

Źródło: opracowanie własne na podstawie notowań giełdowych oraz sprawozdań finansowych spółek giełdowych prezentowanych w serwisie „Notoria”. * Obliczenie dla roku 2004 częściowo zostały oparte na prognozach wyników dla niektórych analizowanych spółek.

\section{Przesłanki wykupu akcji własnych}

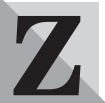
godnie z art. 362 kodeksu spółek handlowych $^{4)}$ jedynie w wyjątkowych przypadkach spółka może nabywać własne akcje. Przykładowo może to dotyczyć następujących sytuacji:

- nabycia akcji w celu zapobieżenia poważnej szkodzie,

- nabycia w celu umorzenia,

- nabycia akcji, które mają być zaoferowane pracownikom lub osobom, które były zatrudnione w spółce.

Decyzja o wykupie własnych akcji prowadzi do zmniejszenia liczby akcji będących w obrocie na rynku kapitałowym. Późniejsze umorzenie zmniejsza liczbę akcji, liczbę tytułów własności. Korzyści ekonomiczne dzielone są na mniejszą liczbę akcji. Jednakże powinien być spełniony warunek: mniejszy kapitał pozwala utrzymać na odpowiednim poziomie działalność oraz wyniki operacyjne. Wykup akcji w porównaniu z dywidendami daje możliwość realizacji wypłat w dłuższym czasie. Wydatki dywidendowe skoncentrowane są w krótszym okresie i stanowią w tym czasie większe obciążenie dla spółki. Ponadto adresowane są do wszystkich akcjonariuszy. Wykup dotyczy jedynie części akcjonariatu, który pozytywnie odpowie na propozycję wykupu. Stwarza to spółce, jak i jej akcjonariuszom większą elastyczność.

W wielu przypadkach należy ostrożnie analizować wszelkie konsekwencje wykupu akcji. Niekiedy bowiem wykupy nie prowadzą do zmniejszenia liczby akcji. Dotyczy to przykładowo sytuacji, gdy sa one nabywane w celu ich zaoferowania kierownictwom firm. Dlatego też wykup nie poprawia w prosty sposób wskaźników liczonych na jedną akcję. Sam w sobie nie prowadzi do wzrostu spółki.

Wskazać można na następujące przesłanki wykupu akcji własnych ${ }^{5)}$.

- W wyniku wykupu poprawia się księgowy obraz spółki. Niekiedy następuje również poprawa realnych wyników ekonomicznych.

- Zapowiedź wykupu stanowi sygnał o bieżącym niedowartościowaniu kursów akcji przez rynek kapitałowy, o różnicach między bieżącą wyceną rynkową a wartością fundamentalną. Zapowiedź wykupu ma doprowadzić w krótkim okresie do wzrostu cen akcji (por. tab. 5).

- Kierownictwo spółki wysyła informacje o nadwyżkach środków pieniężnych będących aktualnie w dyspozycji lub osiągalnych w przyszłości. W krótkim okre- sie środki te nie mogą być w wystarczająco efektywny sposób zagospodarowane w spółce. Kierownictwo firmy stawia te środki do dyspozycji akcjonariuszy.

- Dzięki wykupom akcjonariusze mogą w optymalny sposób dokonać alokacji swoich kapitałów. Nie ograniczają się do projektów inwestycyjnych danej spółki. Wpływa to na rozwój gospodarki jako całości.

- Pozyskane z wykupów akcje własne przeznaczone dla kierownictwa spółek zmniejszają koszty agencji. W nowej sytuacji kierownictwo staje się współwłaścicielem spółki.

- Wykupy akcji i w ten sposób zmniejszenie zaangażowanego kapitału zapobiega podjęciu nieefektywnych inwestycji, które moga doprowadzić do zmniejszenia wartości spółki. Następuje przekazanie nadwyżkowych środków finansowych właścicielom. Uwzględnione zostają możliwości inwestycyjne akcjonariuszy.

- Wykupy prowadzą do ustalenia bardziej korzystnej (optymalnej) struktury kapitału. Prowadzi to do zmniejszenia kosztu kapitału.

- Do wykupów mogą zachęcać adresowane do kierownictwa systemy motywacyjne nastawione na maksymalizacje wyników finansowych przypadających na jedną akcję. W tym przypadku jest ważne, aby zapobiec realizacji pozornych działań mających na celu jedynie poprawę „papierowych” wyników spółki.

Znaczenie poszczególnych motywów zmienia się w czasie wraz ze zmianą obciążeń podatkowych, stanem koniunktury gospodarczej, perspektywami rozwoju poszczególnych sektorów, strukturą akcjonariatu. Poszczególne badania empiryczne (przytoczone w przypisach) wskazują na różną wagę każdego z tych motywów. Przykładowo inwestorzy instytucjonalni sa w większym stopniu zainteresowani wykupami i jednocześnie mają możliwości minimalizacji obciążeń podatkowych.

\section{Specyfika decyzji o wykupie akcji własnych}

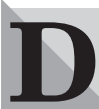

ecyzje o wykupie są jednocześnie decyzjami inwestycyjnymi i finansowymi. Wpływaja na ukształtowanie nowej struktury kapitału i z reguły prowadzą do wzrostu zadłużenia. Poprzez wykup następuje zagospodarowanie nadwyżki środków finansowych. Takie działanie jest wyrazem optymistycznych przekonań kierownictwa firmy co do przyszłości firmy, o tym, że inwestycja ta stanowi najkorzystniejszy sposób wykorzystania nadwyżek środków finansowych, daje najkorzystniejszą z uwagi na 
wysokość i rozkład w czasie stopę zwrotu. Wykup jest inwestycją, która ogranicza, a niekiedy wyklucza podjęcie innych inwestycji. Wykup akcji powinien wykreować dodatkową wartość dla akcjonariuszy. Uzależnione jest to oczywiście od ceny płaconej za wykupywane akcje.

Decyzja o wykupie akcji własnych jest związana z wieloma zjawiskami, które utrudniają ocenę procesu wykupu.

- W wyniku wykupu zmienia się struktura kapitału, co utrudnia wycenę wag w średnim ważonym koszcie kapitału.

- Zmienia się ryzyko działania jednostki, pojawiaja się koszty trudności finansowych na skutek wzrostu zadłużenia.

- Zmienia się koszt kapitału własnego. Firmy ratingowe niekiedy negatywnie oceniają wykupy jako przedsięwzięcia ryzykowne, które pozbawiają spółkę niezbędnego zasobu potrzebnego do działania w przyszłości, np. w sytuacjach pogorszenia koniunktury ${ }^{6}$.

- Zmienia się ryzyko kredytowe i koszt długu. Niekiedy ma miejsce większe uzależnienie od pożyczkodawców, wpisujacych do umów kredytowych niekorzystne klauzule, znacząco ograniczające swobodę decyzyjną.

- Zmienia się struktura akcjonariatu. Nowi właściciele oczekuja realizacji nowych strategii, oczekują innych korzyści. Przenosi się to na inny rozkład przepływów pieniężnych generowanych dla poszczególnych dostawców kapitałów własnych i pożyczkowych. Kształtuje się inny rozkład sił przetargowych między poszczególnymi grupami interesariuszy.

- Kreowane są nowe sposobności, nowe opcje dla kierownictwa oraz dla akcjonariuszy. Mogą oni z nich skorzystać dopiero w warunkach nowej struktury właścicielskiej.

- Wykupy prowadzą do eliminacji wielu sposobności, ograniczają elastyczność w podejmowaniu decyzji. Wynika to ze zmiany struktury finansowania.

- Niekiedy zostają ograniczone możliwości wzrostu firmy. Wykup zmniejsza dysponowane własne środki, zmniejsza możliwości zaciągania kolejnych pożyczek. Powoduje to konieczność skoncentrowania uwagi na problemach utrzymania płynności w krótkim okresie ${ }^{7)}$.

- Zmienia się strategia działania firmy. Wynika to m.in. z konieczności jej dopasowania do nowej sytuacji w zakresie struktury kapitału ${ }^{8}$. Sposób finansowania wpływa na powstanie kryzysowej sytuacji, co oddziałuje nie tylko na wartość firmy, ale również wymusza podjęcie innych niż standardowe decyzji operacyjnych oraz prowadzi do zmiany np. struktury organizacyjnej ${ }^{9}$.

- Decyzje o wykupach podejmowane są w warunkach asymetrii informacji. Niekiedy jedynie kierownictwo zna prawdziwe przesłanki wykupu akcji oraz późniejszą strategię firmy.

Powyższe czynniki utrudniają obiektywną wycenę przepływów pieniężnych i wycenę stopy dyskontowej. Utrudniają dokonanie w sposób standardowy, np. metodą dyskontowania przepływów pieniężnych (DCF), oceny efektywności decyzji o wykupie.

Wadą wykupów jest to, że kierownictwo firmy może ukształtować wygodną dla siebie, a niekoniecznie dla wszystkich akcjonariuszy strukturę kapitału. W krań- cowej sytuacji przejmuje kontrolę nad spółką. Wykupy mogą doprowadzić do znaczącej zmiany struktury kapitałowej i struktury akcjonariatu. W dalszej perspektywie mogą wykreować nowe konflikty między różnymi grupami interesów. Jednocześnie wykup niekiedy zapobiega powstaniu konfliktów poprzez ukształtowanie „zaprzyjaźnionej” struktury akcjonariatu.

\section{Wnioski}



ykupy akcji własnych zaczynają odgrywać coraz większą rolę w strategicznych decyzjach spółek. Dotyczy to zarówno rynków kapitałowych krajów rozwiniętych, jak również rynku polskiego. W ten alternatywny dla dywidend sposób dokonywany jest transfer korzyści do właściciela. Decyzje o wykupie własnych akcji należą do najtrudniejszych w firmie. Są decyzjami o charakterze finansowym i inwestycyjnym. Wpływają również na możliwości prowadzenia działalności operacyjnej. Zmieniaja ryzyko firmy, strukturę kapitału oraz strukturę akcjonariatu. W wyniku wykupu akcji własnych kreowane są prawa opcyjne, które wpływają na efektywność decyzji i wartość firmy. Decyzje o wykupie należy rozpatrywać w kontekście przedsięwzięć, które mogą dać pożądane efekty dopiero w dłuższym okresie. Wykupy akcji stanowią element długookresowej strategii firmy.

dr Andrzej Rutkowski

Wydział Zarządzania Uniwersytetu Warszawskiego PRZYPISY

1) S.G. BADRINATH, N.P. VARAYA, R.L. FERLING, Share Repurchases: To Buy or Not to Buy, „Financial Executive International", maj 2001.

2) Por. m.in.: A. DULINIEC, Operacje wykupu przez spótke wtasnych akcji, [w:] D. ZARZECKI (red.), Zarzadzanie finansami: cele - organizacja - narzędzia t. 2, Wydawnictwo Uniwersytetu Szczecińskiego, Szczecin 2001, s. 373, A. DURAJ, Wptyw umorzenia akcji na wyptate dywidendy przez publiczne spótki akcyjne, [w:] J. DURAJ (red.), Przedsiębiorstwo na rynku kapitatowym, Wydawnictwo Uniwersytetu Łódzkiego, Łódź 2005, s. 273 i nast. oraz artykuły: U. MALINOWSKA, Operacje buy-back w polskich warunkach, M. WYPYCH, Umorzenie akcji i wyptata dywidend a wycena rynkowa spótki, A. RUTKOWSKI, Rachunek efektywności wykupu akcji wtasnych, zamieszczone, [w:] J. DURAJ (red.), Wartość przedsiębiorstwa $z$ teorii $i$ praktyki zarzadzania, Wydawnictwo Novum, Płock 2004.

3) B.E. GUP, D. NAM, Stock Buybacks, Corporate Performance, and EVA, „Journal of Applied Corporate Finance”, vol. 14, wiosna 2001.

4) Kodeks spółek handlowych - Ustawa z 15 września 2000 r., Dz.U. nr 94 z 2000 r. wraz z późniejszymi zmianami.

5) Por. m.in.: G. GRULLON, R. MICHAELY, Dividends, Share Repurchases and the Substitution Hypothesis, „Journal of Finance", 57, nr 4, kwiecień 2002, G. GRULLON, D.L. IKENBERRY, What Do We Know About Stock Repurchases, „Journal of Applied Corporate Finance” 13, wiosna 2000

6) A. TERGESEN, When Buyback Are Signals to Buy, „Business Week", 1 października 2001.

7) U.C. PEYER, A. SHIVDASANI, Leverage and Internal Capital Markets: Evidence from Leveraged Recapitalization, „Journal of Financial Economics”, marzec 2001.

8) M. LEONE, Debtor's Prison? Researchers Satoo Little Equity May Breed Myopia in Managers, „CFO” wrzesień 2001.

9) Por. Sealed Air Corp.'s Leveraged Recapitalization (A) (HBS 9-294-122). 